\title{
Lithological and Structural Controls on the Development of Aquifer in Basement Rock Dominated Tsalit- Ira River Basin, Tigray, Northern Ethiopia
}

Nata Tadesse

Department of Geology, Faculty of Science, University of Botswana, Gaborone, Botswana (Nata.Tafesse@mopipi.ub.bw).

\begin{abstract}
Lithological and structural controls on the development of aquifers in low-grade Neoproterozoic rocks in Tsalit-Ira River Basin, northern Ethiopia are discussed in this paper. Metavolcanic and metasedimentary rocks represent the low grade basement rocks and are overlain by younger sedimentary and volcanic rocks. Fractures, joints, foliations, faults and shear zones are prominent and dominate secondary structures. Four areas, potential for groundwater are identified using structure and borehole data. They are moderate (Alluvial sediments), moderate to low (volcanics), low (sedimentary rocks) and low to weak potentiality aquifers (basement rocks). Based on borehole and structure data presence of multilayer aquifers, their thickness and productivity are suggested.
\end{abstract}

Keywords: Groundwater, Aquifer, Structures, Basement, Tsalit-Ira Basin, Tigray, Ethiopia.

\section{INTRODUCTION}

Peoples in arid and semiarid areas are generally forced to depend on groundwater to meet the demands of domestic, irrigation, and livestock. Groundwater occurrence depends on many factors like rock type, primary and/or secondary porosity, suitable structures and their degree of interconnectivity. Among different rock types, a rock which is highly porous either primary or secondary supports groundwater transmission and storages. Primary porosity is created by geological processes during formation of the rock whereas secondary porosity is developed later and related to structures. So, it is a subsequent or separate porosity system often enhances the overall porosity of a rock. It may result due to chemical leaching of minerals or generation of fracture system. Sometimes, this may replace the primary porosity or coexist with it. In many rocks like magmatic and others, aquifer systems are developed only due to secondary porosity.

The study area Tsalit-Ira River Basin is located in the Tigray Regional State, northern Ethiopia. Both Tsalit and Ira are the tributaries of Weri River which in turn is one of the major tributaries of the Tekeze River, which is a tributary of the Blue Nile River. The basin experiences arid to semi-arid conditions and groundwater is the main source of domestic and livestock water supply. Both urban and rural peoples meet their daily water demand from the scattered springs, hand dug wells and boreholes drilled in the different rocks in the area. Recently activities related to 
groundwater exploration and its development is on rise in the area to meet the increasing demand. Accordingly groundwater exploration activities mainly related to site selection for groundwater supplies are on rise. As part of this initiative, a study was conducted focusing on the hydrogeological conditions and identifying potential aquifers in Tsalit-Ira River Basin. The results of the study are presented in this paper.

\section{THE STUDY AREA}

Tsalit-Ira River Basin is located between $13^{\circ} 50^{\prime} 28^{\prime \prime}$ to $14^{\circ} 15^{\prime} 00^{\prime \prime} \mathrm{N}$ and $39^{\circ} 00^{\prime} 00^{\prime \prime}$ to $39^{\circ} 12^{\prime}$ 13" E covering an area of about $578 \mathrm{~km}^{2}$ (Fig. 1). The study area is bounded by subdivides of the tributaries of Weri River in east and west; drainage divide between the Tekeze River basin and Mereb River basin is north; and Weri River in south. The area is characterized by undulating topography with plateaus, benches, high and rugged mountains, deep river gorges, volcanic cones, volcanic domes, plugs, rolling plains and low lands. Elevation varies between 1500 to $2857 \mathrm{~m}$ above sea level and the area is drained by two major rivers: Tsalit and Ira.

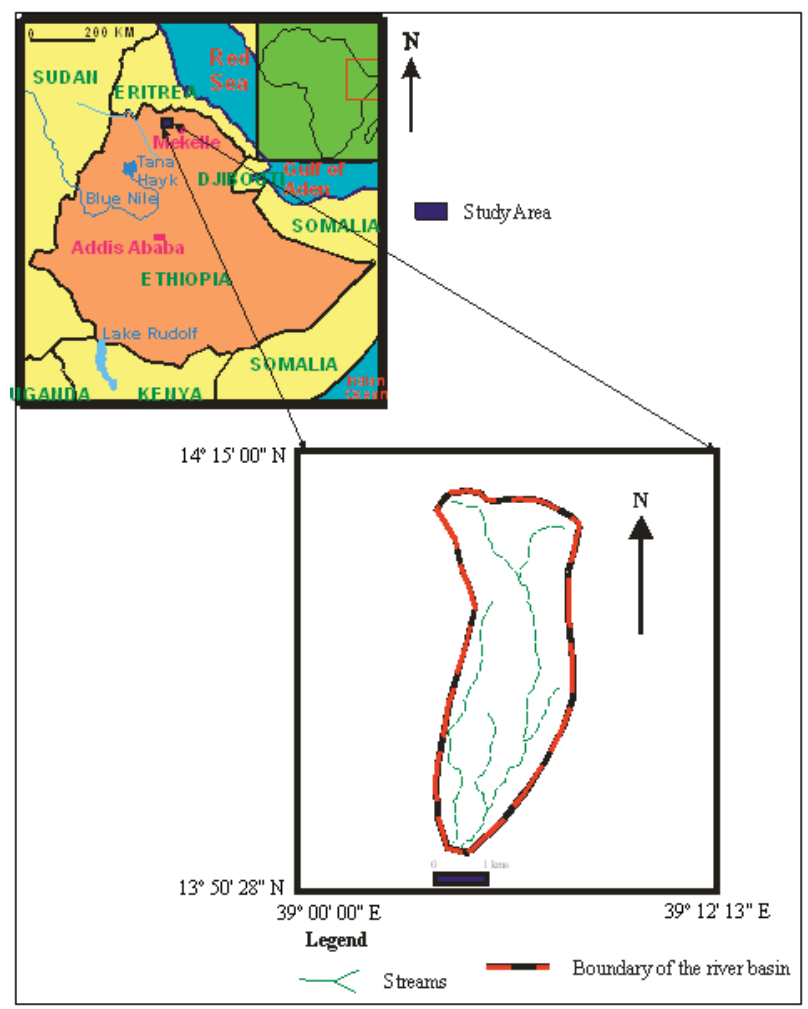

Figure 1. Location map of the study area. 
Tsalit River is $63.28 \mathrm{~km}$ long and flows from northern highlands towards southwest and joins Weri River. Ira River on the other hand is $38.55 \mathrm{~km}$ long flows from highlands in the west towards southwest and joins Weri River. The drainage pattern is rectangular type.

\section{METHODOLOGY}

The topographic map of 1:50,000, sheet 1339 A1 and 1439 C3 and aerial photographs are used for preparing geological map and recording geological structures. Different lithologies were noted based on their megascopic observations and geological structures, fractures, joints, faults, folds, bedding were marked with their orientations on the geological map. Dominant trends and concentration of the structures were used as a basis to relate them with the potential aquifer systems. Assessment of groundwater potential was done on the basis of the available lithological logs and pumping test data. For those geological formations where such data are not available the assessment was done based on field observations and available lithological logs and borehole pumping test data for the same rock type in the adjacent areas. On the basis of the results, the areas potential for groundwater aquifers are demarcated. Based on the primary and secondary data geological and hydrogeological maps are prepared for the area.

\section{RESULTS AND DISCUSSION}

\subsection{Geology of the Area}

The area forms part of Precambrian stratigraphy of northern Ethiopia and comprised of the lithologies ranging from Neoproterozoic to Quaternary in age. The rocks are comparable and related to Tsaliet and Tambian Groups. From bottom to top the lithologies are basement rocks (metavolcanics and metasediments) of Neoproterozoic age, Sedimentary rocks of Phanerozoic and Mesozoic age and followed by volcanic rocks of Quaternary age. The details are given below and also in figure 2 .

\subsubsection{Basement Rocks}

These rocks are of Neoproterozoic age and comprised of weakly metamorphosed acidic to basic volcanic, pyroclastics and sediments with well preserved primary structures (Kazmin, 1972; Beyth, 1973; Garland, 1980). However, the primary sedimentary structures are preserved only in areas where the secondary deformational structures are not pervasive. The rocks are classified 
into two major units, metavolcanics and metasediments. They are covering about $47.5 \%$ of the area and exposed in central, eastern, southeastern, western, southwestern, and southern parts of the area.

\subsubsection{Metavolcanics and Metavolcaniclastics}

Metavolcanic rocks dominate metavolcaniclastics, are fine grained, vary from basic to acidic and are closely associated with metavolcaniclastic rocks. However, intercalations with metavolcaniclasts and metasediments are common. These rocks vary in color from gray to green are the oldest basement rocks in the Proterozoic succession of Tigray region and belong to Tsaliet Group (Kazmin, 1972; Kazmin, 1975; Garland, 1980). The name of the Group is derived from Tsalit River and the area forms the type area. The rocks cover about $15 \%$ of the area and trending towards NNE-SSW direction. The rocks are deformed, folded and sheared (Fig 3A). Overall thickness of the rocks as measured from the section is about $200 \mathrm{~m}$ and they range in elevations from 1680 to $1976 \mathrm{~m}$ above sea level. Metavolcaniclastic rock is comparatively minor and shows presence of different size clasts. Shape of the clasts varies from angular, elliptical and sub-rounded indicating effects of deformation (Fig. 3A).

\subsubsection{Metasediments}

The rocks slate, phyllite and black limestone represent metasediments, occupying relatively low elevated (1840 to $1880 \mathrm{~m}$ ) areas and cover about $32.5 \%$ of the study area.

\subsection{Slate/Phyllite}

It covers about $27 \%$ of the study area and forming NE-SW trending parallel and dissected hills with undulating topography. Its lower contact with metavolcanics is exposed in many places and is characterized by close to vertical dips and deformation (Fig 2B and C). Intercalations with carbonate rocks is common upper contact and grades into calcareous slate with frequent impure, grey limestone beds of about 60 to $90 \mathrm{~mm}$ thick. This transitional character prevails (about 30 to $40 \mathrm{~m}$ ) upto the younger overlying black limestone. Phyllite rock is fine grained, thinly laminated, strongly cleaved and has variegated colors (buff yellow, grey, olive green and variable reddish tinted) and about $100 \mathrm{~m}$ thick. The rock shows closely spaced joints, frequent kink-bands and shear zones (Fig 3C). Petrographic studies by Tadesse (1997) reported that slate is composed of $50 \%$ sericite, $40 \%$ quartz, $8 \%$ feldspar and up to $2 \%$ opaque minerals. The calcareous slate, on the other hand, is composed of $25 \%$ sericite, $20 \%$ micritic calcite, $35 \%$ 


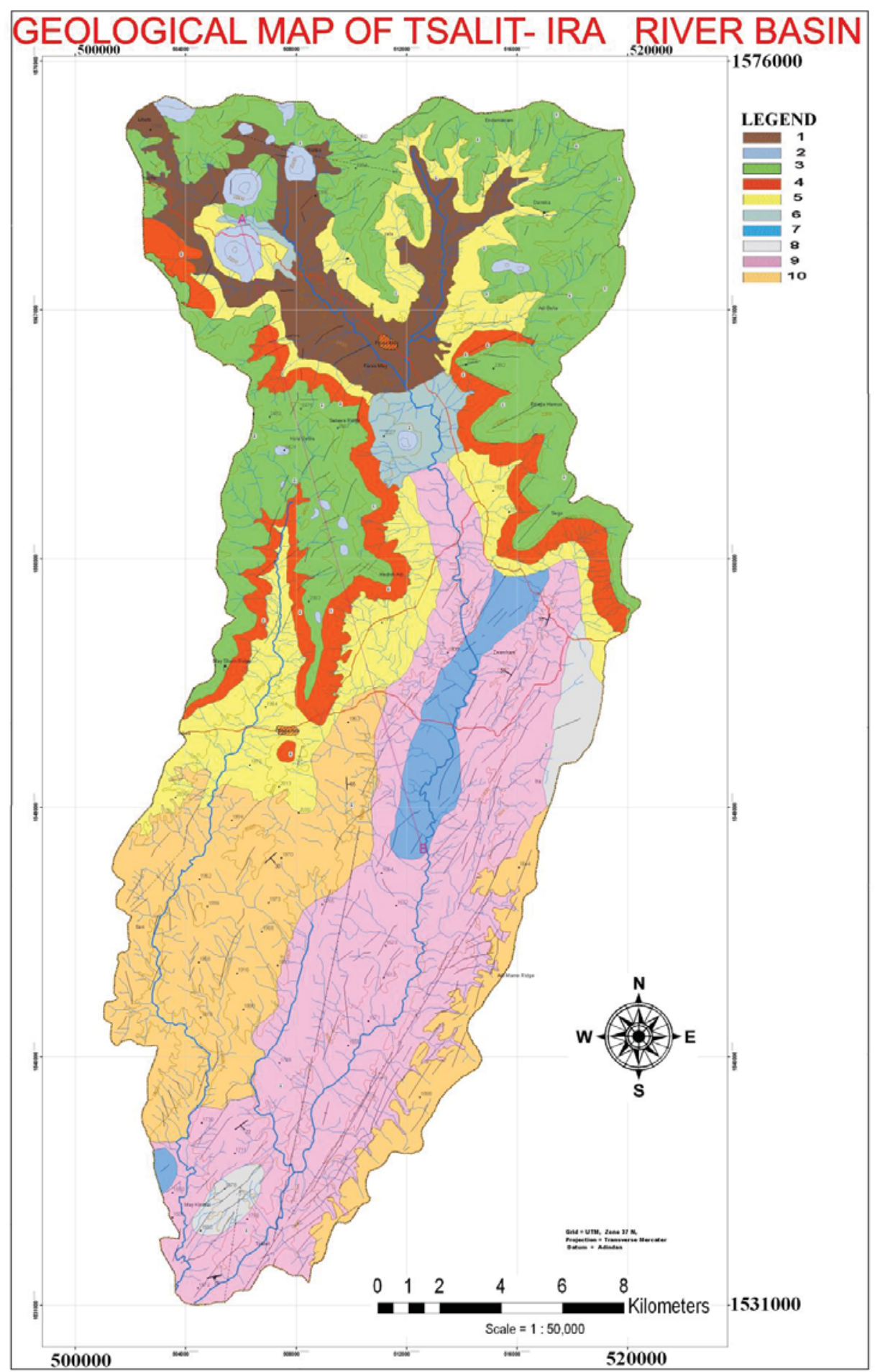

Figure 2. Geological map of the Tsalit- Ira River Basin. (1. Alluvial deposits; 2. Plugs; 3. Basalts; 4. Adigrat Sandstone; 5. Edaga Arbi Tillite; 6. Enticho Sandstone; 7. Metalimestone; 8. Metalimestone \& Slate intercalation; 9. Slate; and, 10. Metavolcanics). 

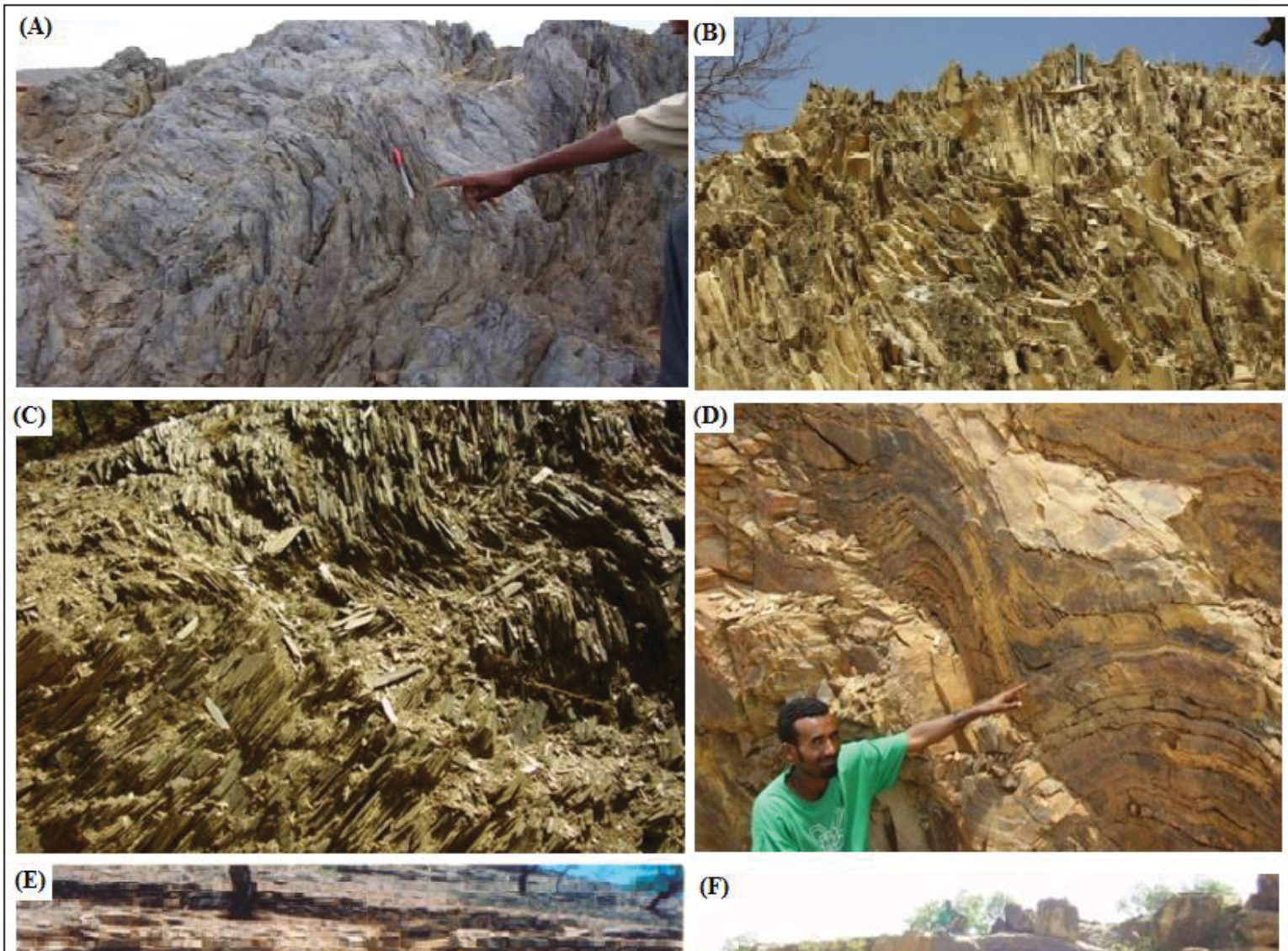

(F)

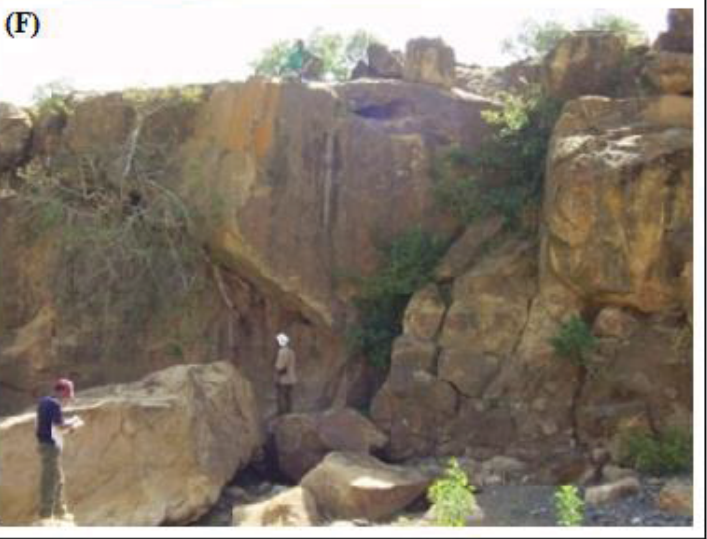

Figure 3. Field photographs, A) massive metavolcanic rock from SW part; B) phyllite with foliations in central part; C) Shear zone in phyllite in central part, D) kink-band folds from central parts, E) black limestone in central part; E) Enticho Sandstone.

quartz, $18 \%$ feldspar and $2 \%$ opaque minerals. The grain size is generally fine ( 0.1 to $0.2 \mathrm{~mm})$, with occasionally large, sub-rounded grains of quartz and feldspars. These larger grains are generally deformed, marginally mortared and commonly possess indistinct sub-grain boundaries. The alignments of sericite along with the dimensional orientation of quartz and feldspar minerals define the fabric of the rock (Tadesse, 1997). 


\subsection{Intercalation of Black Limestone and Slate}

These rocks with NE-SW orientation are covering about $1.5 \%$ of the area and dominated by limestone beds with variegated colors. The intercalated resistant limestone beds and relatively soft slate are producing an alternating positive and negative topography and give the unit striped feature. Among the coarse and fine grained limestone beds, the coarse grained and crystalline variety are common with about $<10$ to $70 \mathrm{~cm}$ thick, rarely $>1.2 \mathrm{~m}$, at places, contains mud lenses and possibly algal fragments. The fine grained beds varies in color from black to pale gray and cream color, generally impure and contains detrital materials such as mica, quartz and feldspar grains, thinly bedded, and laminated, cross-bedded/laminated and contain ripple marks. Diagenetic features such as septarian concretions and dolomitizations are also noted. Calcite veinlet's are the most common in the thicker limestone beds, cross-cut each other and are commonly arranged in an en-echelon fashion. Thickness estimation of the unit is approximate as there are numerous upright folds which repeat part of the unit in short distances. Accordingly, its thickness varies from 20 to $40 \mathrm{~m}$. The unit, in general, is highly jointed and weathered.

Petrographic studies of the slate and limestone rock thin sections carried out by Tadesse (1997) suggests that the composition of the calcareous rocks range between calcite limestone, which is composed of $98 \%$ calcite with little dolomite, calc-arenite which has an average composition of $45 \%$ feldspar, $30 \%$ quartz, $22 \%$ calcite and up to $3 \%$ sericite. The slate on the other hand, is composed of $50 \%$ sericite, $20 \%$ quartz, $15 \%$ feldspars, $12 \%$ calcite and accessory oxide grains.

\subsection{Black Limestone}

Though, this unit is present in the central and southern parts of the study area and forms NE-SW trending a continuous ridge and cover about $4 \%$ the study area. The unit is characterized by black, fine grained, thickly bedded to massive limestone. The total thickness of the unit varies from 40 to $70 \mathrm{~m}$. As it is not covered by any younger strata, the thickness is the remaining part after erosion and the original thickness of the unit must be more than the measured thickness. The unit is characterized by the presence of breccias-like appearance where angular limestone fragments/clasts of variable size ranging from $70-400 \mathrm{~mm}$ wide and about $1 \mathrm{~m}$ long are present. The clasts are cemented by thin, vein-like, a relatively crystalline black calcareous material. At places, they are in iron-rich ferruginous matrix. This unit is affected by the development of fractures, non-systematic joints, at places deformation, karstification and fracture filling calcite 
veins (Fig 3E). Petrographic study of this rock by Tadesse (1997) suggests that both the cementing material and the clasts are composed of microcrystalline calcite with fine grained siliceous impurities.

\subsubsection{Paleozoic and Mesozoic Rocks}

The outcrops of Enticho Sandstone and Edaga Arbi Tillites of Paleozoic age are noted in the central, northern, eastern and western parts of the basin and cover about $2.5 \%$ and $10 \%$ of the area respectively. They unconformably overlie the Precambrian basement rocks and form small hills with irregular slopes and underlie the cliff forming Adigrat Sandstone. Tillites are glacial deposits and may be correlated either with the Late Carboniferous glacial rocks of southern Africa or the Ordovician glacial rocks of Hoggar district of southern Algeria (Dow et al., 1971). The Paleozoic sedimentary rocks are overlying the Mesozoic Adigrat Sandstone.

\subsubsection{Enticho Sandstone}

About $160 \mathrm{~m}$ thick and is composed of white color, coarse grained, cross-bedded, calcareous sandstone containing lenses of siltstone, grit and polymict conglomerate with sub-rounded to well-rounded pebbles, cobbles and boulders. Scattered irregular clasts of granite and gneiss are also common at places. It shows poorly sorted grains of quartz indicating immature character. Lower part of this sandstone is massive whereas the upper part shows well developed crossbedding and also isolated non-penetrative fractures (Fig 3F). It is generally found occupying areas that range in elevation from 2000 to $2180 \mathrm{~m}$ above sea level.

\subsubsection{Edaga Arbi Tillite}

Varies in thickness from 10 to $100 \mathrm{~m}$, shows fresh grey color, form small hillocks, produce an undulating topography with gentle slopes, rarely with steep slopes, overlain by Adigrat Sandstone and occupy areas that range in elevation from $1960 \mathrm{~m}$ to $2040 \mathrm{~m}$. These rocks are characterized by the presence of greywacke (about 20 to $50 \mathrm{~m}$ thick) dominated basal part having lithic fragments such as gneiss, granite and metavolcanics ( $>500 \mathrm{~mm}$ size) with striations in a fine grained matrix. The Tillites about 50m thick show well developed laminations of siltstone and claystone with variegated colors like grey, green, red. The lower part is dominated by siltstone ( $\sim 50 \mathrm{~cm}$ thick) and the upper part is dominated by finer harder calcareous and dolomitic layers. Variation in the composition and development of thin laminations with pebbles overlying the basal Tillites suggests a cyclic nature of their deposition. These rocks being quite soft are 
highly weathered and show presence of fractures with different orientations. Tillites are at places overlie Enticho Sandstone and at places are inter-fingered but not underlying Enticho Sandstone.

\subsubsection{Adigrat Sandstone}

Constitutes about $6 \%$ of the area, show yellow, red and pink colors, with well sorted fine to medium grained quartz in non-calcareous cement, and shows well developed ripple marks and cross-bedding Presence of lenses of red colored siltstones, conglomerates and beds of laterite (2$20 \mathrm{~m}$ thick) are common. Joints are well developed, mostly vertical and quite deep. The rock is about $120 \mathrm{~m}$ thick in the vicinity of Edaga Arbi town, western part of the study area and ranges in elevation from $2000 \mathrm{~m}$ to $2200 \mathrm{~m}$. It forms hills, ridges, cliffs and scarps and overlie Tillites. Presence of thin layers of red and grey/white color fine sand is quite common indicating the periods of aerobic and anaerobic conditions during deposition. Presence of lenses of conglomerate and quartz pebbles represents channel deposits. This rock overlie either on Paleozoic sedimentary rocks or basement rocks and belong to Upper Triassic to Middle Jurassic age based on the younger overlying Antalo Limestone is considered to be Upper Jurassic (Mohr, 1963) and considered younger to the same in the eastern Ethiopia which is Triassic in age (Garland, 1972a,b).

\subsubsection{Volcanic Rocks}

Represented by the Tertiary, stratified basaltic rocks, trachyte and phonolite plugs (The Adwa Formation) and cover about $22 \%$ and $3 \%$ respectively of the area. These volcanics occupy highest parts in the topography forming hills with rugged topography and present in the eastern, north-eastern, northern, north-western and western parts of the study area.

\subsubsection{Basaltic Rocks}

Dominant among the volcanic, covers almost whole northern part of the area except few places and is overlying the Paleozoic/ Mesozoic sedimentary rocks. In eastern, northeastern, western and northwestern parts of the area they overly the lateritic Adigrat Sandstone. About 30 to $100 \mathrm{~m}$ thick, and form part of the early flood basalts and belong to Trap (Plateau) Series, erupted from fissures during the Early and Middle Tertiary and represent the second major pulse of fissurerelated basalt volcanism in the northwestern plateau of the country. These are transitional basalts mainly with tholeiitic composition, generally aphyric, compact, and at places show stratification and rarely with inter-bedded basic tuffs. These basalts show moderate values of $\mathrm{Al}_{2} \mathrm{O}_{3}$ (13-14\%) 
and $\mathrm{TiO}_{2}(2.5-3.1 \%)$, and $\mathrm{K}_{2} \mathrm{O}$ contents $(0.4-1.1 \%)$ and lie between alkaline and MORB tholeiitic basalt compositions (Zanettin, 1993). The basalts are found forming plateau and dome shaped topography that have a slope ranging from steep to flat and occupy areas that ranges in elevation from 1984 to $2250 \mathrm{~m}$.

\subsubsection{Trachyte and Phonolite}

These rocks typically occur as plugs reported first by Blanford (1870), form part of Adwa Formation, overlie and intrude the basalts. Adwa-Senafe area is considered as type locality for Adwa Formation (Plugs) (Garland, 1980). They fine grained, light colored, and occur as pipes and plugs with alkaline composition. They are typically massive, hard and occupy highest peaks up to $2400 \mathrm{~m}$ in the topography and show flow structures, columnar jointing and concentric exfoliation. Dominantly fine grained, but occasionally phenocrysts of orthoclase occur in a matrix of other feldspars including pink colored orthoclase in trachyte and green colored about $10 \%$ aegirine.

\subsubsection{Unconsolidated Sediments}

Quaternary sediments are quite scarce in the Tsalit-Ira River Basin and present in the areas underlain by volcanic rocks and as thin strips along the margins of the Tsalit-Ira River and its tributaries. Sediments, as alluvial terraces are seen with limited areal extent. Residual soils are developed on the bedrock with variable thickness. Thin sediment cover occurs in the eastern, northeastern, northern, northwestern, and western parts of the area overlying the plateau. The sediments mainly black cotton soil, rich in clay and range in thickness from 3-9 $\mathrm{m}$, but mostly between 6-9 $\mathrm{m}$ formed due to weathering of the underlying basalts. Alluvial sediments are found as thin strips along the margins of the Tsalit-Ira River and its tributaries in both highlands and lowlands. Relative abundances and stratigraphic relations of the sediments are not uniform in the basin. Towards the mountains front, where steep topographic slopes exist and the gradient of the rivers is high, the alluvial sediments are dominated by sub-angular to subrounded coarse grained particles with variable content of coarse grained sand. In the southwestern parts of the area where the gradient of the rivers is decreases down slope, the dominant alluvial deposit contain medium to fine grained sand with variable content of silt and clay. Generally, thickness of the sediments, as was observed in galleys and open hand dug well, is ranging from 5 to $7 \mathrm{~m}$. 
After the Pliocene volcanic activity, the fluvial processes and the slope evolution involved in the formation of platform and plateau together with the exhumation of the Paleozoic erosion surface and the accumulation of alluvial fans, fluvial terraces and infilling valleys (Machado et al., 1994). Successive phases of down cutting and alleviation are found in the main tributaries of the Tsalit-Ira River, Ira Shet' represented as alluvial terraces.

Despite the apparent similarity, these terrace deposits show some differences not only in their composition but also in the thickness and the clasts size. In general, these deposits have a thickness ranging from $2-5 \mathrm{~m}$ with rounded gravels of $13-15 \mathrm{~cm}$ in average grain size, with some boulders ranging between $40 \mathrm{~cm}$ and $1 \mathrm{~m}$, composed of metavolcanics, vein quartz and schist. In general, terrace deposits cover about 9\%, and occupy 1984 to $2250 \mathrm{~m}$ elevation.

\subsection{Structures}

Most common structures found in different rock types in the investigated area are folds, foliations, faults, shear zones, joints, fractures, dikes, bedding and cross bedding.

The low grade Precambrian basement rocks are most conspicuously show development of foliation trending north-south with deviations to northeast and northwest (Fig 3B and C). Primary sedimentary features are very well preserved in some of the metasediments such as bedding. Metavolcanics being volcanic origin they are massive. The basement rocks are clearly folded into asymmetric synclines and anticlines, and in some cases they are even re-folded into two synclines. Different types of folds recorded in these rocks are anticlinal, synclinal, harmonic and kink-band folds (Fig 3D). Mostly the structures are quite prominent as expected in phyllites followed by in others. Sinistral strike slips faults with N-NE orientation are common in the basement rocks. There are several major lineaments as observed in satellite imageries, some of them are over 50 kilometers and are associated with several faults and overthrusts. Joints and fractures are common structures observed almost in all lithologies. These structures may be related to extensional/tensional or shear forces. In the area, joints are identified as transversal and non-systematic. The non-systematic joints are curved and show irregular geometry in all lithologies. The opening width of these joints in different lithologies ranges from $0.01-30 \mathrm{~cm}$. Their general orientations are $\mathrm{N} 45^{\circ} \mathrm{E}, \mathrm{N} 50^{\circ} \mathrm{E}, \mathrm{N} 80^{\circ} \mathrm{E}, \mathrm{S} 85^{\circ} \mathrm{E}$ and $\mathrm{S} 10^{\circ} \mathrm{E}$. 
The fractures vary in width from 1 to $120 \mathrm{~cm}$ and show $\mathrm{N} 70^{\circ} \mathrm{W}, \mathrm{N} 45^{\circ} \mathrm{E}, \mathrm{E}-\mathrm{W}$ and $\mathrm{N} 15^{\circ} \mathrm{E}$ orientations in the rocks of the study area. The structure trends are shown using rose diagram in figure 4.

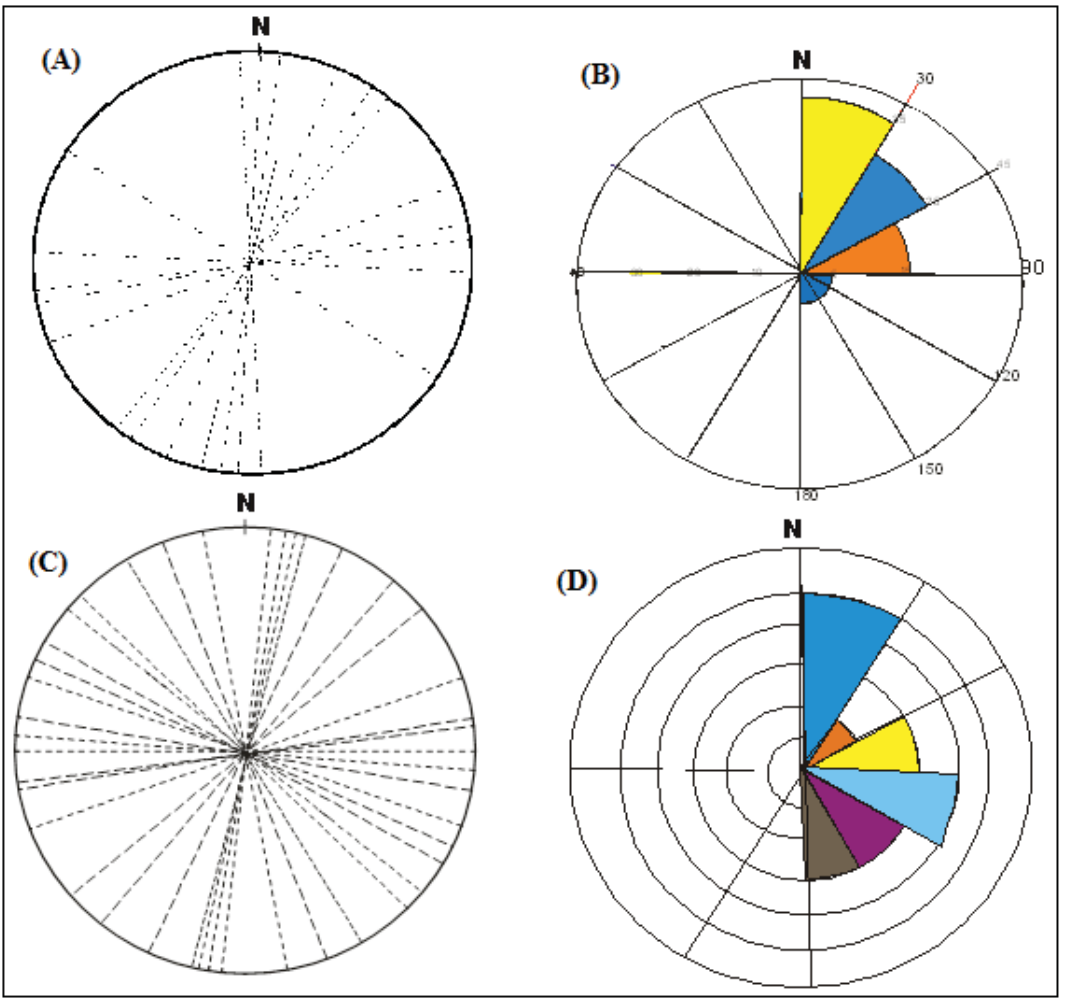

Figure 4. Rose diagram showing the orientation of the structures, (A) and (B) indicate the fractures in metasediments and (C) and (D) .the fractures in metavolcanics.

The shear zones, which are dominantly found in the metasediments, are common structures in the basement rocks of the mapped area. The general orientation is almost north-south. These shear zones are regionally extensive and the rock is highly brecciated and shattered. The study area is also characterized by the presence of dykes showing $\mathrm{N} 50^{\circ} \mathrm{E}$ and $\mathrm{S} 50^{\circ} \mathrm{W}$ trends. These dykes vary in texture from fine grained aplitic to coarse grained granitic. Mostly, they are found parallel to the foliation. Columnar joints are also present in the dykes. The bedding plane of the sedimentary rocks or relict on metasedimentary rocks in the studied area is generally dipping towards north to $\mathrm{N} 75^{\circ} \mathrm{E}$ with dip amount ranging from $20^{\circ}-79^{\circ}$. Cross bedding is commonly observed in the volcanoclastic, metasediments and Enticho Sandstone. The major orientation of cross-bedding structures is $\mathrm{N} 22^{\circ} \mathrm{W}$ and $\mathrm{N} 45^{\circ} \mathrm{W}$. It forms foresets which is an inclined stratum. 
Quartz veins are commonly found in the basement rocks of the studied area. They occur in various sets as concordant as well as discordant veins. Calcite veins are ubiquitous particularly in the black limestone. They are generally clean white and have en-echelon arrangements.

\subsection{Hydrogeological Characteristics}

Water bearing capabilities of different rock types and unconsolidated sediments in the area particularly with reference to their water storage and transmission is discussed below.

\subsubsection{Metamorphic Rocks}

The weathered and fracture zones are the main sources for groundwater supply in metamorphic rocks. These are interpreted on the basis of the geological logs available in the study area (Fig 5 A and B). Since the Precambrian of the mapped area contains heterogeneous types of rocks, the lithology and texture of these rocks influence the thickness and permeability of the weathered zones. The thickness of the weathered zone in the metasediments and in the associated metasediments of the metavolcanics varies from 3 to 36 meters, most being between 12 to 30 meters. These rocks give rise to thick weathered layers. However, the weathered products are largely clayey materials as revealed from boreholes. These clayey materials by themselves are saturated formations which, although capable of absorbing water slowly, will not transmit it fast enough to yield a significant supply for a well. In addition, these secondary materials very often sealed the fractures, which facilitate the flow of water through the rock, and by this decrease the porosities and hydraulic conductivities of the fractures and, therefore, the yields of wells penetrating these fractured rocks. This low productivity is also indicated by the low discharge of hand dug wells and boreholes that are found drilled in this unit. In metavolcanic rocks of the mapped area, although the weathered zones are more or less equally thick, the weathered products have a lesser clay content, and also have more open joints and fractures.

In addition to weathered zones, fracture zones also are of great importance in the metamorphic terrains as the low-grade metamorphic rocks with fractures and joints facilitate storage and movement of groundwater through them. The width of fractures openings are generally less than $1 \mathrm{~cm}$ and occur more frequently near the ground surface but become rarer with depth as revealed from borehole logs. However, the interconnectivity of these fractures and joints, which leads to greater hydraulic conductivity, is greatly reduced by clayey materials which filled them. Due to 
this reason, the fracture zones serve as poor aquifers; low productive aquifers. The north-south faults and fractures of these rocks are the principal conduits for vertical infiltration.

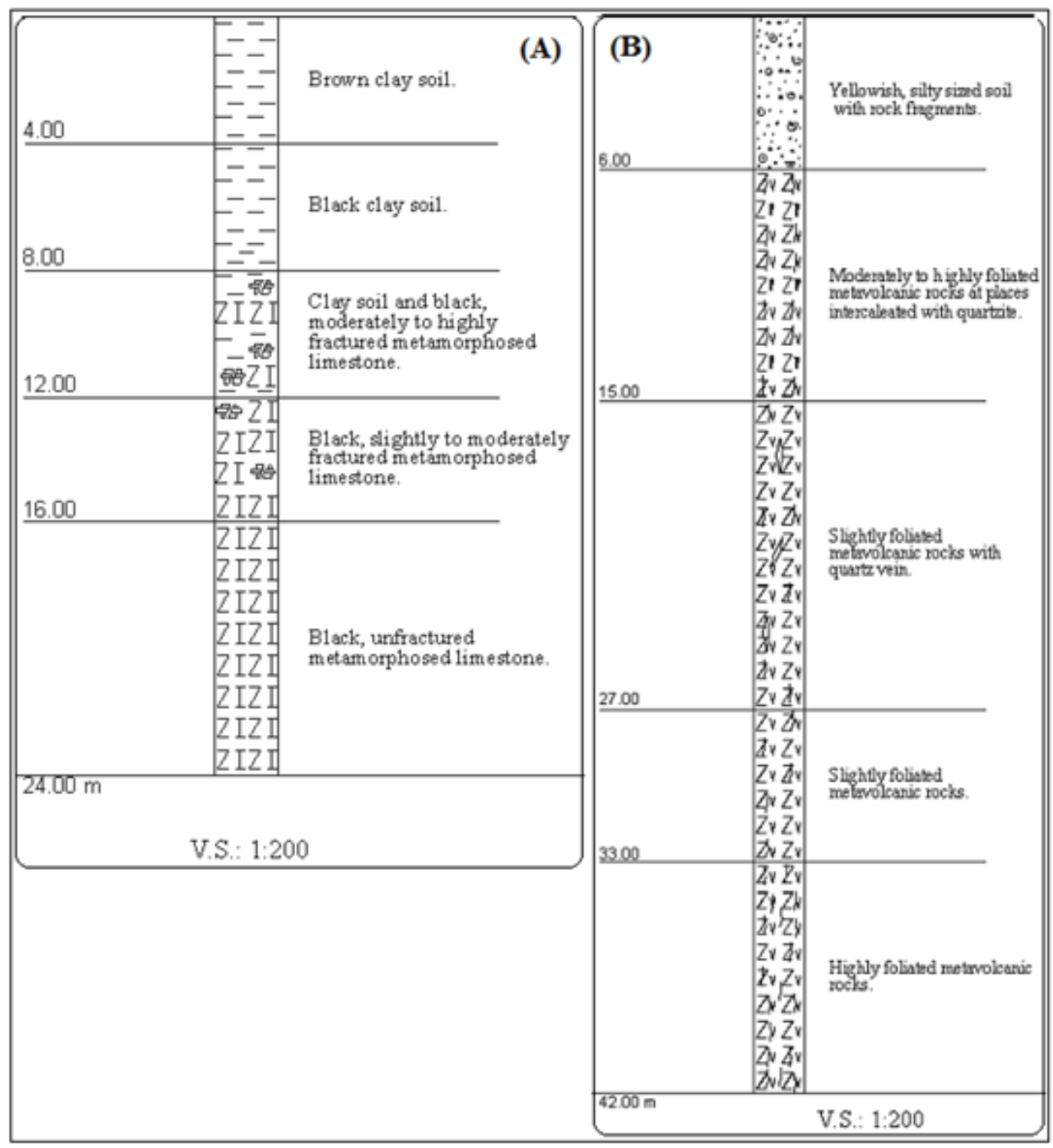

Figure 5. Lithological log for a well, A) Workamba and B) Daero Kerni.

The schistocity and foliation planes are inlets for infiltration of water, but only to a limited depth. Generally the metavolcanics have a lesser clay content and more open joints than the 
metasediments, and therefore are more permeable than the latter under the same fracturing and weathering conditions (Tesfaye, 1993).

A number of boreholes were drilled in the metamorphic rocks of the basin. The productivity of the different metamorphic rocks aquifers were evaluated based on available pumping test data of these boreholes. More than 20 boreholes have been found drilled in this formation. The depth of these boreholes ranges from $37 \mathrm{~m}$ to $69.5 \mathrm{~m}$. The static water level ranges from $1 \mathrm{~m}$ to $15.3 \mathrm{~m}$ below ground surface. The yield ranges from 1 1/s to 7.4 1/s. The drawdown ranges from $1.29 \mathrm{~m}$ to $18.30 \mathrm{~m}$. The computed hydraulic conductivity is ranging from 0.26 to $2.56 \mathrm{~m} /$ day with a mean value of $0.771 \mathrm{~m} /$ day and transmissivity is ranging from 3.33 to $56.47 \mathrm{~m}^{2} /$ day with a mean value of $16.77 \mathrm{~m}^{2} /$ day.

\subsubsection{Paleozoic and Mesozoic Rocks}

\subsubsection{Enticho Sandstone}

In this rock secondary porosity due to fracturing is of significance. Fracturing has increased its void space as well as its capacity for water transmission and enhanced its usefulness to the water supply. However, in some parts, it has a high degree of cementation which reduces its permeability and productivity. Available hand dug wells and borehole data revealed that, in the Enticho Sandstone, the yields of hand dug wells and boreholes range from 0.2 to $6 \mathrm{l} / \mathrm{s}$. The pumping test data of the boreholes in this formation reveals also that the computed transmissivity and hydraulic conductivity of the aquifer in this formation reach up to $32.92 \mathrm{~m} 2 /$ day and 1.426 $\mathrm{m} /$ day, respectively.

\subsubsection{Edaga Arbi Glacials}

Because of the presence of considerable silt and clay and also strong silty-clayey cement which make them completely tight, the Edaga Arbi Glacials have intergranular permeabilities that are very low. A large number of springs discharge at the contact with the overlying sediments. In some areas, however, the fractures impart an enhanced capability for groundwater flow and storage.

The productivity of the aquifers in this formation were evaluated based on available pumping test data of boreholes that are found drilled in this formation. A number of boreholes are found drilled in this formation. The depth of these boreholes ranges from $36 \mathrm{~m}$ to $40 \mathrm{~m}$. The yield ranges from $1.61 / \mathrm{s}$ to $2.51 / \mathrm{s}$. The drawdown ranges from $4.52 \mathrm{~m}$ to $28.17 \mathrm{~m}$. The computed 
hydraulic conductivity is ranging from 0.372 to $1.184 \mathrm{~m} /$ day and transmissivity is ranging from 12.01 to $34.65 \mathrm{~m}^{2} /$ day.

\subsubsection{Adigrat Sandstone}

The assessment of permeability and productivity of the Adigrat Sandstone was carried out based on field observation and analysis of pumping test data of boreholes in the nearby area due to unavailability of both lithological logs and boreholes pumping test data in the mapped area.

Outside the mapped area in the nearby area, the permeability and productivity of the Adigrat Sandstone was evaluated based on pumping test data of boreholes. Accordingly, the Adigrat Sandstone has a moderate permeability and productivity. As it was observed in the field exposures, this degree of permeability and productivity might be due to the limited shale intercalation, bedding planes and the deep vertical jointing. Infiltration and recharge occur mainly through these joints and bedding planes. Its lack of high degree of permeability and productivity might be a result of the medium to fine grain size and degree of cementation. Generally, in the Adigrat Sandstone, intergranular permeabilities are low but secondary porosities and permeabilities due to fracturing are of significance.

In the mapped area, in most places Adigrat Sandstone forms hills, ridges and scarps. These landforms act as runoff zones. Even though limited infiltration can take place along fractures and joints, these landforms make the exploitability of groundwater resource of the formation quite limited because the groundwater availability in these types of landforms in general is very poor. However, a large number of high discharge springs characteristically emerge at the contact of the Adigrat Sandstone with the underlying basement and/or Edaga Arbi Glacials which are often used by the local population for domestic and agricultural purposes. The groundwater also discharges as springs along the narrow valley portions.

\subsubsection{Basaltic Rocks}

The basalts have developed good permeability due to columnar jointing (primary), weathering and fracturing (secondary). The basalts typically exhibit columnar jointing. Joints of this type are formed due to contraction of the cooling lava, forming prismatic patterns in the solidifying rock, and impart good permeability. The columnar joints cause anisotropy and strong vertical hydraulic conductivity in basalts. 
The basalts have also developed good secondary porosity and permeability due to fracturing and weathering. As revealed from boreholes (from the nearby area) the thickness of these fractured and weathered zones as a whole range from $21-75 \mathrm{~m}$. These zones of basalts, which are found underlain the black cotton soil, are aquifers. The depth of these boreholes ranges from $57 \mathrm{~m}$ to $120 \mathrm{~m}$. The static water level ranges from $1.17 \mathrm{~m}$ to $9.26 \mathrm{~m}$ below ground surface. The yield ranges from $1 \mathrm{l} / \mathrm{s}$ to $11 \mathrm{l} / \mathrm{s}$. The drawdown ranges from $16.15 \mathrm{~m}$ to $81.47 \mathrm{~m}$. The computed hydraulic conductivity is ranging from 0.015 to $1.348 \mathrm{~m} /$ day and transmissivity is ranging from 1.67 to $89.86 \mathrm{~m}^{2} /$ day.

\subsubsection{Adwa Formation (Plugs)}

Most of the plugs show wide and deep linear joints in their circular structure which usually don't show displacement. Since the trachyte is hard and massive, it acts as runoff zone; limited infiltration can take place along the above mentioned structures that may have developed as a result of pressure and temperature differences during and/or after the formation of the rock. Due to these structures, the Adwa Formation has a high water transmission capacity. However, Adwa Formation that has these structures still lack any significant porosity, so that its water storage capacity is negligible even though its water transmission ability is high. In general, the Adwa Formation has negligible groundwater potential due to the landform which it forms, small recharge area, steep slopes, lack of significant porosity and very low permeability of massive trachytes.

\subsubsection{Unconsolidated Sediments}

In the Tsalit-Ira River Basin, extensive unconsolidated sediment areas are scarce. Unconsolidated sediments are found in limited thickness and areal extent mainly in the terrain underlying by volcanic rocks and as thin strips along the margins of the Tsalit-Ira River and their tributaries.

Sediments of fluvial origin, such as alluvial terraces, are also found in small areal extent. Less extensive sediments occur in the eastern, northeastern, northern, northwestern, and western parts of the mapped area overlying the plateau. These sediments are derived from the underlying basalts by the process of weathering, and their thickness range from 3 to 9 meters, most being between 6 to 9 meters. These sediments are saturated but poorly permeable stratum that impedes groundwater movement and does not yield water freely to wells. 


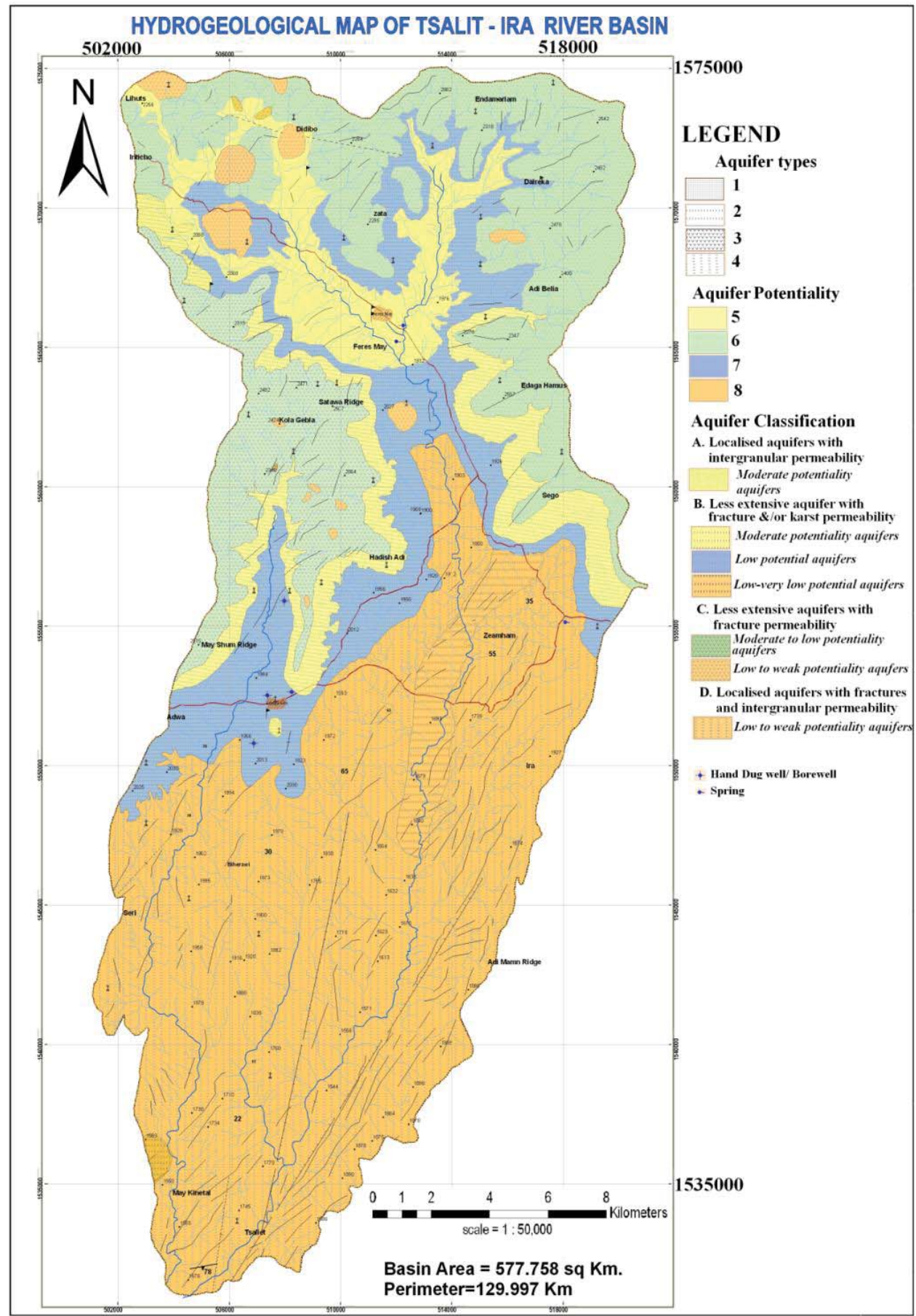

Figure 6. Hydrogeological map of Tsalit-Ira River Basin [Legend- 1 . Localized aquifers with intergranular permeability; 2. Less extensive aquifers with fracture and/or karstic permeability; 3. Less extensive aquifers with fracture permeability; 4. Localized aquifers with fracture and intergranular permeability; 5. Moderate potentiality aquifers; 6. Moderate to low potentiality aquifers; 7 . Low potentiality aquifers; 8 . Low to weak potentiality aquifers. 
Being rich in clay, the sediments have a very low permeability and productivity and serve as confining or semi-confining layers. The poor drainage characteristics of the sediments lead to water logging. Alluvials along the margins of the Tsalit-Ira River and its tributaries are the most common shallow groundwater aquifers which can be tapped by larger diameter hand dug wells. Their permeability and productivity vary from place to place depending on their grain size, sorting and thickness. In the terrace deposits, in general, groundwater is found in the voids of gravels. The alluvial terraces make up potential groundwater reservoirs for local uses. In fact, in the mapped area, they can be the primary locations for water-well excavation to supply the nearby villages.

Assessment of the permeability and productivity of the alluvials (which are found along the margins of the Tsalit-Ira River and its tributaries) and alluvial terraces were carried out based on field observation due to unavailability of both lithological logs and boreholes pumping test data in the areas where these sediments are found. Accordingly, these sediments, as a whole, may be taken to have a moderate permeability and productivity.

\subsection{Groundwater Occurrence}

The geological history of the studied area suggests a complicated hydrogeological environment and a complex groundwater regime. The absence of uniform permeable sediments extending over large areas implicates that extensive aquifers are unlikely to exist in the mapped area. Instead, exploitable groundwater occurrence is limited to isolated areas where the groundwater potential may be a result of fracturing and weathering. About $72.5 \%$ of the total studied area is covered by non-porous crystalline and volcanic rocks. In their original form, these rocks don't have any significant property of water storage and transmission. They are characterized by negligible primary porosity and permeability. However, weathering and fracturing can impart significant secondary porosity and permeability which is highly variable. As a result, the storage and transmission of the groundwater in these rocks is limited and restricted to the weathered zones, joints, fractures, shear zones, faults and other discontinuities.

Groundwater in metamorphic rocks and volcanic rocks occurs under perched, unconfined and confined conditions. Data on the position of the groundwater level in relation to the geological layers revealed that groundwater in Enticho Sandstone and Edaga Arbi Glacials occurs under perched and unconfined conditions. 


\section{CONCLUSION}

The different rocks and unconsolidated sediments in the mapped area which behaves as aquifers have been classified on the basis of the type of permeability which they exhibit and the extent of the aquifer into the following four aquifer areas.

1. Localized aquifers with intergranular permeability (unconsolidated sediments: alluvial sediments along the margins of the Tsalit-Ira River and their tributaries and alluvial terraces);

2. Less extensive aquifers with fracture and/or karstic permeability (Black limestone, Enticho Sandstone, Edaga Arbi Glacials and Adigrat Sandstone);

3. Less extensive aquifers with fracture permeability (Basalts and Plugs); and

4. Localized aquifers with fractured and intergranular permeability (Metavolcanics, Slate, and Intercalation of Black Limestone and Slate).

On the basis of their potentiality, the different rocks and unconsolidated sediments in the mapped area which behaves as aquifers have been classified into four groups. The classification is made on the basis of transmissivity as per Şen, (1995) classification scheme.

1. Moderate potentiality aquifers (Alluvial sediments along the margins of the Tsalit-Ira River and its tributaries, Alluvial terraces and Adigrat Sandstone);

2. Moderate to low potentiality aquifers (Basalt);

3. Low potentiality aquifers (Enticho Sandstone and Edaga Arbi Glacials);

4. Low to weak potentiality aquifers (Metavolcanics, Metasediments and Plugs).

Further investigation using geophysical technique and borehole testing is suggested to understand the subsurface extent of the different structures and vertical thickness of the different formations and the presence of additional multilayer aquifers, their respective thickness and productivity. Water quality investigation (i.e. for domestic purpose) is also recommended.

\section{ACKNOWLEDGMENTS}

This research was funded by the Federal Democratic Republic of Ethiopia, Ministry of Water Resources in 2007 to be conducted in one year. The financial assistance is highly acknowledged. 


\section{REFERENCE}

Beyth, M. 1973. Correlation of Paleozoic-Mesozoic sediments in Northern Yeman-Tigray and Northern Ethiopia. Bull. Am. Ass. Pet. Geol. Bull. 57:2440-2443.

Blanford, W. T. 1870. Report on the Geology of a Portion of Abyssinia. Geol. Soc., London, Q. J., 25: 401-406.

Dow, D. B., Beyth, M \& Tsegaye Hailu. 1971. Paleozoic Glacial Rocks Recently Discovered in Northern Ethiopia. Geol. Magazine, 108 (1):53-60.

Garland, C. R. 1972. Explanation of the Geological Map of Adigrat Sheet (ND 37-7), 1:250,000 Scale. Ethiopian Institute of Geological Survey, Addis Ababa.

Garland, C. R. 1972. Geological Map of Adigrat Area, 1:250,000 (ND 37-7). Ethiopian Institute of Geological Survey, Addis Ababa.

Garland, C. R. 1980. Geology of Adigrat Area, Ministry of Mines, Energy and Water Resources, Memoir no. 1:51.

Kazmin, V. 1972. Geological Map of Ethiopia, 1:2,000,000 Scale. Ethiopian Institute of Geological Survey, Addis Ababa.

Kazmin, V. 1975. Explanatory Note to the Geology of Ethiopia. Ethiopian Institute of Geological Survey, Bulletin no. 2, Addis Ababa.

Machado, M. J., Pèrez-Gonzales, A \& Benito, G. 1994. Rehabilitation of Degraded and Degrading areas of Tigray-Northern Ethiopia, Geological Framework of the Adwa-Weri Area, Progress Report, University of Trieste, Italy.

Mohr, P. A. 1963. Geological Map of the Horn Africa, 1:2,000,000 Scale. Philip and Jacey, London.

Tadesse, T. 1997. Geology of Axum Area, Ethiopian Institute of Geological Survey, Memoir No. 9, Addis Ababa.

Tesfaye Chernet. 1993. Hydrogeology of Ethiopia and Water Resources Development, Ethiopian Institute of Geological Survey, Addis Ababa.

Zanettin, B., 1993. On the Evolution of Ethiopian Volcanic Province, From Geology and Mineral Resources of Somalia and Surrounding Areas, Ist. Agron.Oltremare, Firenze, Relaze Monogram. 113, 279-310. 